\title{
Short Communication: \\ Growth rate of Acropora muricata coral fragments transplanted on dome-shaped concrete artificial reef with different composition
}

\author{
FARID KAMAL MUZAKI ${ }^{1, \vee}$, RISKHA HANIFA ${ }^{1}$, RUDHY AKHWADY ${ }^{2}$, DIAN SAPTARINI ${ }^{\mathbf{1}}$, BUHARIANTO ${ }^{3}$ \\ ${ }^{1}$ Marine Biodiversity and Conservation Research Group, Ecology Laboratory, Department of Biology, Faculty of Science, Institut Teknologi Sepuluh \\ Nopember. Jl. Arief Rahman Hakim, Surabaya 60111, East Java, Indonesia. Tel./fax.: +62-31-5963857. •email: rm_faridkm@bio.its.ac.id \\ ${ }^{2}$ Research and Development Bureau, Ministry of Marine Affairs and Fisheries Republic of Indonesia. Jakarta Utara 14430, Jakarta, Indonesia \\ ${ }^{3}$ Slolop Marine Conservation Community. Bungatan, Situbondo 68358, East Java, Indonesia
}

Manuscript received: 19 March 2019. Revision accepted: 8 May 2019

\begin{abstract}
Muzaki FK, Hanifa R, Akhwady R, Saptarini D, Buharianto. 2019. Short Communication: Growth rate of Acropora muricata coral fragments transplanted on dome-shaped concrete artificial reef with different composition. Biodiversitas 20: 1555-1559. Artificial reefs are artificial habitats laid in waters by mimicking some of the characteristics of natural reefs; and could be made of different materials, one of which is concrete. Seashell waste and stone ash could be added as an alternative material to the concrete for artificial reefs. The purpose of this research is to access the growth rate of Acropora muricata coral fragments transplanted on the hollow domeshaped concrete with three different compositions: C1), conventional concrete, composed by a mixture of Portland cement, sand, and gravel (composition was 1:3:2); C2), a mixture of Portland cement, sand and crushed bivalve's shells (composition was 1:3:2); and C3), a mixture of Portland cement, stone waste (stone dust), sand and crushed bivalve's shells (composition was 1:3:3:2). Observation of coral fragment growth was conducted underwater by Scuba diving for six months with observed parameters were fragment length, colony diameter and a number of branching. The highest rate of fragment lengthening of $\mathrm{A}$. muricata coral fragment was at $\mathrm{C} 2$ $(1.019 \pm 0.081 \mathrm{~cm} /$ month $)$ and $\mathrm{C} 1(1.014 \pm 0.076 \mathrm{~cm} / \mathrm{month})$. The highest colony diameter increment was also in $\mathrm{C} 2(1.903 \pm 0.212$ $\mathrm{cm} /$ month $)$ and $\mathrm{C} 1(1.856 \pm 0.219 \mathrm{~cm} / \mathrm{month})$; while largest number of branches was also in $\mathrm{C} 2(13.31$ or $2.21 \mathrm{branch} / \mathrm{month})$ and $\mathrm{C} 1$ (12.56 or 2.09 branch/month), respectively. Based on one-way ANOVA and Tukey's HSD test ( $p=0.05)$, there is no significant difference in fragment lengthening and colony diameter in $\mathrm{C} 1$ and $\mathrm{C} 2$ model, yet differed significantly with the $\mathrm{C} 3$ model.
\end{abstract}

Keywords: Acropora muricata, artificial reefs, growth, rock ash, shell waste, transplantation

\section{INTRODUCTION}

Bivalves are aquatic molluscs that show a fundamental bilateral symmetry. Their characteristic shell is composed of two calcified valves lying on the right and left sides of the body (Poutiers 1998). They are economically important and highly potential to be utilized as a protein source (Eshmat et al. 2014). The volume of bivalve production in Indonesia keeps increasing from 2003 to 2007 by 2.869 , $12.991,16.348,18.896$ and 15.623 tonnes, respectively (Eshmat et al. 2014).

The significance increment of production and consumption of bivalves may cause a problem of increasing wastes of bivalve's shells that have been discarded. Therefore, a high amount of solid waste shells produced requires serious efforts to handle, in order to reduce the negative impacts on humans and the environment (Agustini et al. 2011).

Shells wastes have low economic value and usually disposed of in landfill as solid waste (Olivia et al. 2017; Nguyen et al. 2017). In Indonesia, shells wastes are also commonly used as some craft materials such as souvenirs or interior design materials (Agustini et al. 2011). Other uses including mixed material for animal feeds or calciumrich cookies (Agustini et al. 2011; Nguyen et al. 2017) and abrasive materials in toothpaste (Ahmad 2017). Another alternative use of the seashell wastes are as raw material for making adsorbents in water management (Anugrah et al. 2015; Wahyudianto 2016) or concrete materials for artificial reefs (Agustini et al. 2011; Permana et al. 2014).

Artificial reefs are artificial (man-made) structures deployed on the seafloor and mimicking some of the characteristics of natural reefs (Dhiecha et al. 2013) and are typically built to promote marine life in areas with a generally featureless bottom. Deployment of artificial reefs is expected to attract marine organisms to live and settle so it can increase fisheries production, as well as restore shallow water marine habitat (i.e., coral reefs). Artificial reefs are usually made from unused materials such as tires, shipwrecks or concrete materials (Dhiecha et al. 2013).

All seashells wastes are primarily composed of naturally formed calcium carbonate $\left(\mathrm{CaCO}_{3}\right)$ which in the form of calcite mineral. The main chemical composition of seashells is similar to limestone, primarily consisting of calcium oxide $(\mathrm{CaO})$, while $\mathrm{CaO}$ composition in seashells was found to vary between $48.0 \%$ and $86.8 \%$ (Mo et al. 2018). This property made seashells available to be used as materials for concrete production and reported that they could produce good quality concrete (Cuadraco-Rica et al. 2015; Nguyen et al. 2017). 
Concrete, which is one of the best materials for artificial reef (Subhan et al. 2014) is used in terms of durability and material and has surfaces and cracks that suitable for settlement of marine organism (Dhiecha et al. 2013). The concrete material is relatively sturdy and durable and is not easily shifted or swept away by waves; concrete substrate also contains calcium, so it is expected to accelerate coral growth (Alfeche 2002; Soong and Chen 2003).

Concrete applications for artificial reefs are often combined with coral transplantation, which is principally a coral colony propagation technique based on asexual reef reproduction by fragmentation (Johan 2003, 2012; Subhan et al. 2014). A study to access the growth rate of coral fragments transplanted on concrete substrates made from a mixture of seashells wastes is needed. The results are expected to be baseline data for the recommendation of seashells wastes utilization.

\section{MATERIALS AND METHODS}

\section{Study area}

The research took place in the area of Batu Lawang reef, Pasir Putih Beach, Situbondo, East Java. Concrete as a substratum for coral transplantation deployed at 4-5 meter depth on the seabed in empty spaces among coral colonies. Bottom substrates composed by a mixture of sand and coral rubble. Visibility ranged from 8 meters at the rainy season and exceeding 12 meters at dry season; surface current velocity is moderate $(10.4 \mathrm{~cm} / \mathrm{s})$ and mainly generated by tidal actions (Figure 1).

Visual observation in the area shows that coral colonies on the reef flat dominated by massive, encrusting, branching and submassive Acroporid and some branching coral (non-Acroporid) lifeforms. At the level of genus, massive and encrusting lifeform dominated by Porites, Goniastrea and Montastrea, whereas branching lifeform dominated by Setiatopora and Pocillopora. Several lifeforms of Acroporid occurred in the area; including branching (i.e., Acropora muricata, which is dominant species, A. florida, and A. nasuta), tabulate (i.e., A. hyacinthus), digitate (i.e., A. humilis) and submassive (A. palifera).

\section{Composition of concrete}

The concretes are dome-shaped with a dimension of 50 $\mathrm{cm}$ high and $50 \mathrm{~cm}$ in diameter (Figure 2). Three different types of concrete were used: $\mathrm{C} 1$ ), conventional concrete which composed by a mixture of Portland cement, sand, and gravel (composition was 1:3:2); C2), a mixture of Portland cement, sand and crushed bivalve's shells (composition was 1:3:2); and C3), a mixture of Portland cement, stone waste (stone dust), sand and crushed bivalve's shells (composition was 1:3:3:2), respectively. We have built ten units for each type of concrete, therefore, a total of 30 units were available for this study.

\section{Coral transplantation}

Fragment of A. muricata for transplantation was collected from adjacent large donor colonies. Donor colonies must be visually healthy (i.e., not bleached nor partially covered by algae) and the size of fragments used in this study are $10 \mathrm{~cm}$ (Muzaki, 2008). Four coral fragments planted on each concrete. Fixation of coral fragments to concrete (as a substratum for transplantation) using cable ties on steel nails previously mounted on the concrete. Each fragment then labeled with a waterproof paper sheet containing data including number and type of concrete and also the number of fragment.

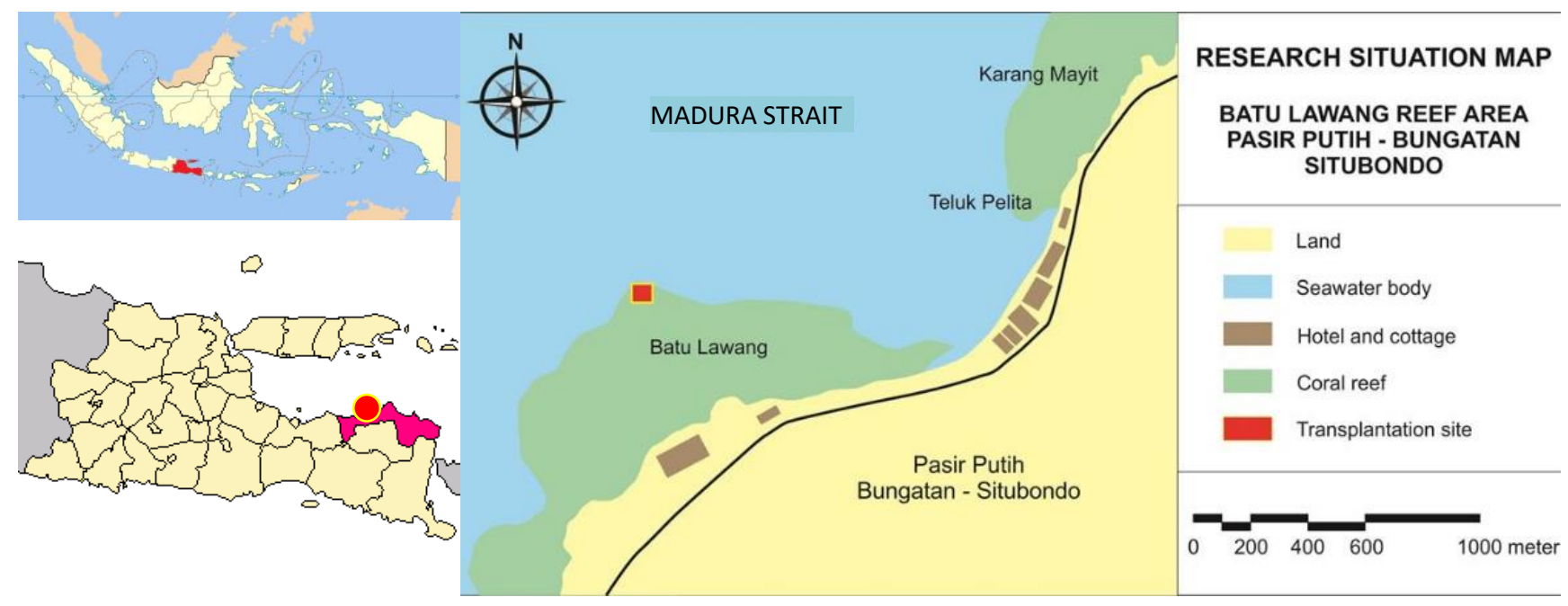

Figure 1. Research situation map in Batu Lawang reef, Pasir Putih, Bungatan, Situbondo, East Java, Indonesia 


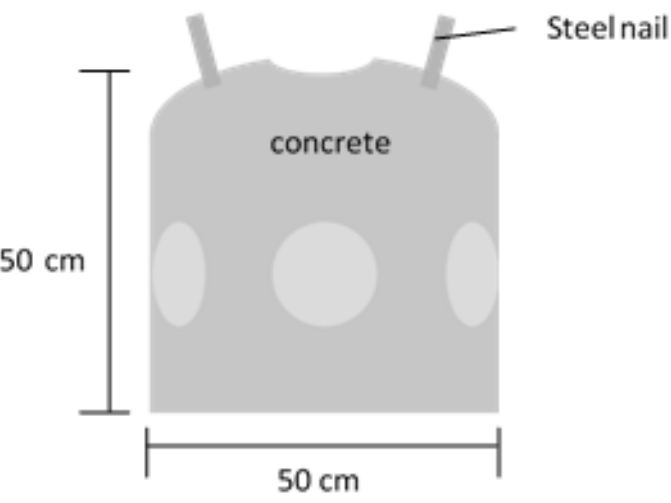

Figure 2. Concrete model used as substratum in coral transplantation

After being transplanted, the length of all coral fragments was re-measured using a caliper to gain initial length (T0). Growth observation including the lengthening of coral fragments was performed once every month until the 8th month after transplantation (T7). Data recording was carried out in situ using SCUBA equipment and documented by an underwater camera (Muzaki, 2008). Ambient variables measured were water temperature, salinity, level of dissolved oxygen (DO), alkalinity $(\mathrm{pH})$ and visibility.

\section{Data analysis}

The difference in the length of the coral fragment $(\Delta \mathrm{L})$ is the result of the length of the fragment at the end of the monitoring period (T7) minus the fragment length at the beginning of the monitoring (T0); while lengthening rate of coral fragment is the difference in the length of coral fragments $(\Delta \mathrm{L})$ per unit time (month) as shown in the equation below:

$$
\begin{aligned}
& \Delta L=L_{7}-L_{0} \\
& \nu L=\frac{\Delta L}{t}
\end{aligned}
$$

$L_{7}$ is the length of the branch after seven months, $L_{0}$ is the initial length of the branch, $v L$ is the rate of branch lengthening, and $t$ is time or period of research. A similar approach was applied to calculate the difference in the diameter of the coral colony $(\triangle D)$ and rate of diameter increment $(v L)$. The difference in growth rate (based on lengthening and diameter increment) of coral fragments on each type of concrete was analyzed with one-way analysis of variance (ANOVA, at 95\% confidence level, $\mathrm{p}=0.05$ ), followed by Tukey's HSD test $(p=0.05)$.

\section{RESULTS AND DISCUSSION}

\section{Environmental variables}

Average value of measured environmental variable and quality standard for marine organism are available in Table 1.
Table 1. Results of environmental variables measurement

\begin{tabular}{lccc}
\hline Parameter & Unit & $\begin{array}{c}\text { Average } \\
\text { value }\end{array}$ & QS \\
\hline Salinity & $\% 0$ & $31.67 \pm 0.87$ & $33-34$ \\
Temperature & ${ }^{0} \mathrm{C}$ & $28.95 \pm 0.39$ & $28-30$ \\
DO & $\mathrm{ppm}$ & $7.48 \pm 0.19$ & $>5$ \\
pH & - & $8.05 \pm 0.07$ & $7-8.5$ \\
Visibility & $\mathrm{m}$ & $10.66 \pm 1.80$ & $>5$ \\
\hline
\end{tabular}

Note: QS: quality standard for marine life, based on Ministry of Environment of Republic of Indonesia, Resolution no 51, Appendix III (2004)

Based on Table 1, all of the environmental variables, except for salinity, are still in the range of quality standard for marine life, based on Ministry of Environment of Republic of Indonesia, Resolution no 51 Appendix III (2004). The averaged value for salinity was $31.67 \pm 0.87$ or below the range of quality standard for marine life. However, some other studies stated that corals could tolerate salinity from 23.3 to 41.8 ppt (Kleypas et al. 1999). Therefore, in general, it can be assumed that all environmental variables in the study area are suitable for coral growth.

\section{Growth rate of $\boldsymbol{A}$. muricata coral fragments}

In Scleractinian corals, the skeleton is made of calcium carbonate $\left(\mathrm{CaCO}_{3}\right)$ crystallized in aragonite (orthorhombic system) (Allemand et al. 2004; Tambutté et al. 2011). In order to build their skeleton, corals have to supply calcium and inorganic carbon from ambient seawater (Gattuso et al. 1999; Allemand et al. 2004). In this study, addition of crushed seashell wastes to concrete was intended and expected to provide the coral fragments with more calcium from the seashell wastes, since they contain many $\mathrm{CaCO}_{3}$ which vary between $48.0 \%$ and $86.8 \%$ (Mo et al. 2018); however, it can exceed 95-99\% (Hariahan et al. 2014). Therefore, it can be expected that providing more calcium will result in higher calcification rate, or in other hands, a higher growth rate of coral fragments.

After seven months, A. muricata coral fragments transplanted on three different compositions of concrete show a little higher rate of colony diameter increment in $\mathrm{C} 1$ $(1.856 \pm 0.219 \mathrm{~cm} / \mathrm{month})$ and C2 $(1.903 \pm 0.212 \mathrm{~cm} / \mathrm{month})$ compared to those in C3 $(1.69 \pm 0.211 \mathrm{~cm} / \mathrm{month})$. Measurement of the rate of fragments lengthening shows a similar trend to the rate of colony diameter increment, which fragments in $\mathrm{C} 1$ and $\mathrm{C} 2$ have relatively higher fragments lengthening compared to fragments in $\mathrm{C} 3$. In $\mathrm{C} 1$, the average rate of lengthening was $(1.014 \pm 0.076 \mathrm{~cm} /$ month), in C2 was $1.019 \pm 0.081 \mathrm{~cm} /$ month while in C3 was $0.941 \pm 0.080 \mathrm{~cm} / \mathrm{month}$, respectively. One-way ANOVA test and Tukey's HSD test (both at $\mathrm{p}=0.05$ ) resulted in no significant difference in both diameter increment and branch lengthening of coral colonies in $\mathrm{C} 1$ and $\mathrm{C} 2$ but significantly differed with coral colonies in C3. A similar trend also occurred for the rate of new branches production. $\mathrm{C} 1$ and $\mathrm{C} 2$ concrete have a higher value (2.09 and 2.21 new branches per month) compared to $\mathrm{C} 3$, which was only 1.07 new branch per month. 


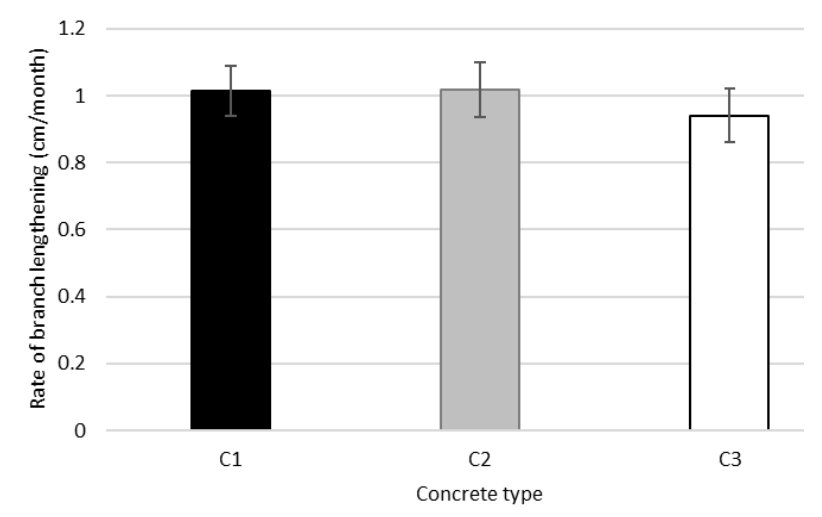

Figure 3. Rate of branch lengthening in A. muricata transplanted on three different compositions of concretes

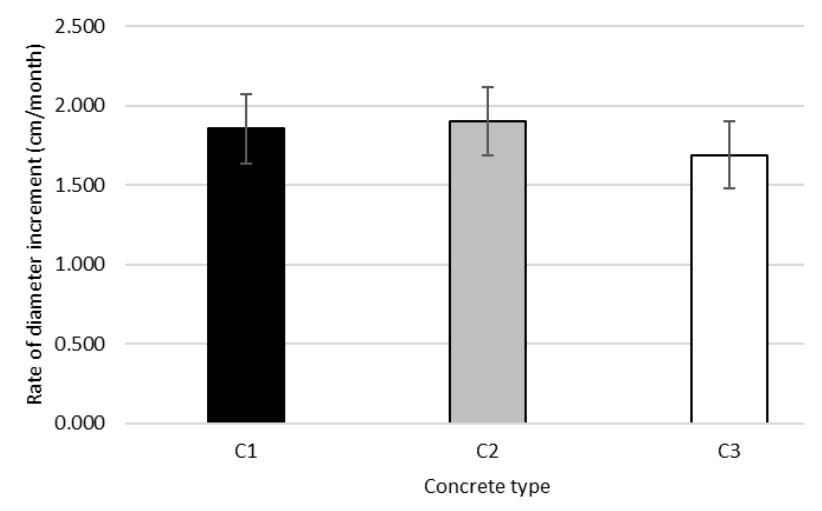

Figure 4. Rate of colony diameter increment in A. muricata transplanted on three different compositions of concretes

In this study, crushed seashells waste used as a substitution of gravel (coarse aggregates) in C2 and C3 concretes. However, this replacement would replacement produced low strength and lightweight concrete compared to conventional concrete (Dahunsi 2003; Nguyen et al. 2013; Olivia et al. 2013). Provision of crushed seashells waste will increase concrete's porosity because of increase of air entrapped in the concrete (Cuadrado-Rica et al. 2015), as well as increasing water absorption due to the irregular surface and high number of pores (Wang et al. 2013; Mo et al. 2018) which in turn would increase the contact of concrete's surface to seawater.

Concrete exposed to seawater will undergo leaching as a result of chemical and physical processes (Suprenant 1991). Such leaching enabling calcium (and other compounds in the concrete) to be diluted in seawater, providing minerals needed by corals for biomineralization. Concerning this, it is expected that coral fragments in $\mathrm{C} 2$ concrete should have a higher growth rate compared to $\mathrm{C} 1$ concrete. However, the results of this study showed that the growth rate of coral fragments in both types of concrete were not significantly differed. This result may be due to the size of seashell waste used which were not in powder but aggregates so the leaching process may not take place in a short time.

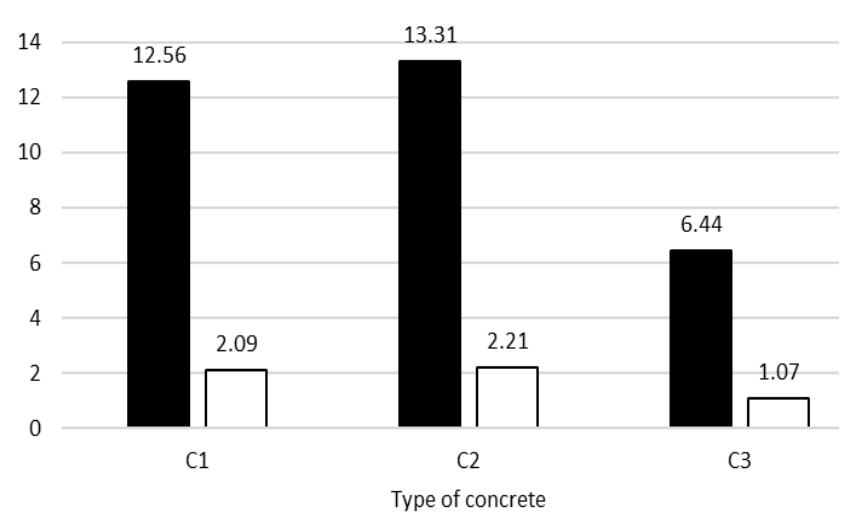

- Total branches $\square$ Branching average

Figure 5. Average total branches after seven months and the rate of new branches production (per month) in A. muricata transplanted on three different compositions of concretes

Meanwhile, the growth rate of coral fragments in C3 concretes were lower than in $\mathrm{C} 1$ or $\mathrm{C} 2$ concretes, although aggregates of seashells waste were also added. This is probably caused by the addition of stone dust (stone ash) that rich in silica and alumina, as well as alkali compound, iron, and calcium even in a small amount. The silica is amorph and will be readily hardened when mixed with cement, forming calcium silicate compounds which are difficult to dissolve in water (Wikana et al. 2014). This hardening by calcium silicate able to inhibits leaching process to occur continuously.

Results of this study suggested that concrete made from crushed seashells waste are possible to be used as artificial reef unit for coral transplantation. However, the provision of seashells waste was assumed to have no significant effect on the rate of lengthening and diameter increment of coral fragments or colonies when compared to conventional concrete.

\section{ACKNOWLEDGEMENTS}

We thank the Ministry of Marine Affairs and Fisheries Republic of Indonesia for funding this research. We also thank Department of Biology, Institut Teknologi Sepuluh Nopember, Surabaya and the local community in Pasir Putih, Situbondo for supporting the research.

\section{REFERENCES}

Agustini TW, Susana ER, Bambang AW, Johannes H. 2011. Pemanfaatan cangkang kerang simping (Amusium pleuronectes) sebagai sumber kalsium pada produk ekstrudat. Jurnal Pengolahan Hasil Perikanan Indonesia 14 (2): 134-142. [Indonesian]

Ahmad I. 2017. Pemanfaatan limbah cangkang kerang darah (Anadara granosa) sebagai bahan abrasif dalam pasta gigi. Jurnal Galung Tropika 6 (1): 49-59. [Indonesian]

Alfeche LR. 2002. Coral reef restoration trough coral transplantation: the case of Duka bay, Medina, Misamis Oriental. Mindanao Polytechnic State College, Misamis Oriental, Filipina. 
Allemand D, Ferrier-Pages C, Furla P, Houlbreque F, Puverel S, Reynaud S, Tambutte E, Tambutte S, Zoccola D. 2004. Biomineralisation in reef-building corals: from molecular to environmental control. Comptes Rendus Palevol 3: 453-467.

Cuadraco-Rica H, Sebaibi N, Boutouil M, Boudart B. 2004. Properties of ordinary concrete incorporating crushed queen scallop shells. Mater Struct 49 (5): 1805-1816.

Dahunsi BIO. 2003. Properties of periwinkle-granite concrete. J Civil Eng 8: 27-35.

Dhiecha DM, Kiki PU, Dian RT. 2013. Perencanaan artificial reef sebagai restorasi terumbu karang pengaman pantai di Pulau Lemukutan Kabupaten Bengkayang. Program Studi Teknik Lingkungan, Fakultas Teknik, Universitas Tanjungpura, Pontianak. [Indonesian]

Eshmat ME, Gunanti M, Boedi SR. 2014. Analisis kandungan logam berat timbal $(\mathrm{Pb})$ dan cadmium $(\mathrm{Cd})$ pada Kerang Hijau (Perna viridis L.) di Perairan Ngemboh, Kabupaten Gresik, Jawa Timur. Jurnal Ilmiah Perikanan dan Kelautan 6 (1): 101-108. [Indonesian]

Gattuso JP, Allemand D, Frankignoulle M. 1999. Photosynthesis and calcification at cellular, organismal and community levels in cora reefs: a review on interactions and control by carbonate chemistry. Amer Zool 39: 160-183.

Harihan M, Neethumol N, Benny A, Sreenivasan PV, Jenish P, Asmy A. 2014. Synthesis and characterisation of $\mathrm{CaCO}_{3}$ (calcite) nanoparticles from cockle shells using chitosan as precursor. Intl J Sci Res Publ 4 (10): $1-5$.

Kleypas JA, McManus JW, Menez LAB. 1999. Environmental limits to coral reef development: where do we draw the line? Amer Zool 39: 146-159.

Ministry of Environment of Republic of Indonesia, Resolution no 51 year 2004, Appendix III.
Mo KH, Alengaram UJ, Jumaat MZ, Lee SC, Goh WI, Yuen CW. 2018. Recycling of seashell waste in concrete: A review. Construct Build Mater 162: 751-764.

Muzaki FK, Saptarini D. 2008. Kecepatan Pertumbuhan Fragmen Karang Acropora formosa dengan Jumlah Percabangan Berbeda. Departemen Biologi Institut Teknologi Sepuluh Nopember, Surabaya. [Indonesian]

Nguyen DH, Boutouil M, Sebaibi N, Leleyter L, Baraud F. Valorization of seashell by-products in pervious concrete pavers. Construct Build Mater 49: 151-160.

Olivia M, Mifshella AA, Darmayanti L. 2015. Mechanical properties of seashell concrete. The 5th International Conference of Euro Asia Civil Engineering Forum (EACEF-5). Procedia Eng 125: 760-764.

Permana DI, Anita SS, Elma Y. 2014. Pengaruh penambahan tumbukan kulit kerang jenis Anadara granosa sebagai agregat halus terhadap kuat tekan beton K-225. Jurnal Bentang 2 (2): 36-46. [Indonesian]

Soong K, Chen T. 2003. Coral Transplantation: regeneration and growth of Acropora fragment in a nursery. Restor Ecol 11 (1): 62-71. [Indonesian]

Suprenant B. 1991. Designing Concrete for Exposure to Seawater. Magazine Engineering, University of Colorado, USA.

Tambutté S, Holcomb M, Ferrier-Pagès C, Reynaud S, Zoccola D, Allemand D. 2014. Coral biomineralization: From the gene to the environment. J Exp Mar Biol Ecol 408: 58-78.

Wang H, Kuo W, Lin C, Po-Yo C. 2013. Study of the material properties of fly ash added to oyster cement mortar. Construct Build Mater 41: 532-537.

Wikana I, Wantutrianus. 2014. Pengaruh pemakaian fly ash abu batu sebagai pengganti sebagian semen pada kuat tekan beton mutu tinggi. Majalah Ilmiah UKRIM 1: 41-52. [Indonesian] 